\title{
PENGGUNAAN STATIN DAN ANTIPLATELET SEBAGAI PENCEGAHAN SEKUNDER KOMPLIKASI KARDIOVASKULER PADA PASIEN DIABETES MELITUS TIPE 2
}

\author{
Pande Made Desy Ratnasari ${ }^{1}$, Putu Dian Marani Kurnianta², Anak Agung Ngurah Putra Riana \\ Prasetya $^{1}$ \\ ${ }^{1}$ Program Studi Sarjana Farmasi, Sekolah Tinggi Farmasi Mahaganesha, Denpasar, Indonesia \\ ${ }^{2}$ Program Studi Diploma Tiga Farmasi, Sekolah Tinggi Farmasi Mahaganesha, Denpasar, Indonesia
}

Kata Kunci :

statin, antiplatelet,

diabetes melitus tipe 2 ,

komplikasi

kardiovaskuler

\section{ABSTRAK}

Resistensi insulin pada pasien diabetes melitus (DM) tipe 2 dapat meningkatkan risiko terjadinya komplikasi kardiovaskuler yang selanjutnya dapat berkontribusi sebagai penyebab utama kematian. Resistensi insulin meningkatkan kerentanan pasien mengalami aterosklerosis dan menimbulkan gangguan pada fungsi platelet di pembuluh darah yang dapat berdampak pada peningkatan risiko komplikasi kardiovaskuler. Sebagai salah satu upaya untuk mencegah dan mengurangi risiko tersebut, Canadian Cardiovascular Society Guidelines tahun 2011 dan American Diabetes Association tahun 2019 merekomendasikan penggunaan golongan statin dan antiplatelet sebagai upaya pencegahan sekunder komplikasi kardiovaskuler pada pasien DM tipe 2 . Penelitian ini bertujuan untuk mengetahui gambaran penggunaan statin dan antiplatelet sebagai pencegahan sekunder pada pasien DM tipe 2 dengan komplikasi kardiovaskuler. Penelitian ini bersifat observasional dengan desain cross sectional yang dilakukan pada 110 pasien di RSU Puri Raharja Denpasar Bali periode November 2019. Hasil penelitian menunjukkan bahwa dari 110 pasien yang memenuhi kriteria penggunaan statin, hanya 42 pasien (38,1\%) yang menggunakan statin (simvastatin $20 \mathrm{mg}$; 95,2\%). Selain itu, dari total 96 pasien yang memenuhi kriteria penggunaan antiplatelet, hanya 52 pasien $(47,3 \%)$ yang menggunakan antiplatelet (aspirin $80 \mathrm{mg} ; 82,7 \%$ ). Penelitian ini merefleksikan penggunaan statin yang masih rendah dalam upaya pencegahan sekunder komplikasi kardiovaskuler pada pasien DM tipe 2. Meskipun terdapat kecenderungan tingkat penggunaan antiplatelet aspirin yang lebih tinggi daripada statin dalam penelitian ini, pemberian aspirin selanjutnya masih perlu ditingkatkan lagi bersama-sama dengan peningkatan pemberian statin.

\section{PENDAHULUAN}

Diabetes Melitus (DM) merupakan penyakit kronik yang menjadi salah satu masalah kesehatan di dunia (1). International Diabetes Federation memprediksikan jumlah penyandang DM di dunia pada tahun 2019 yaitu 463 juta orang dan diperkirakan akan terus mengalami peningkatan hingga tahun 2045 yaitu 700,2 juta orang (2). Indonesia menempati peringkat keenam di dunia dengan jumlah penyandang DM sebesar 10,3 juta jiwa (3). Data World Health Organization (WHO) pada tahun 2019 menunjukkan bahwa sebesar 9095\% dari kasus DM adalah DM tipe 2 (4). Di Indonesia sendiri DM tipe 2 menjadi penyebab kematian terbesar pada urutan ketiga setelah stroke dan penyakit jantung koroner (5).

Resistensi insulin pada pasien DM tipe 2 dapat meningkatkan risiko terjadinya komplikasi kardiovaskuler yang selanjutnya dapat berkontribusi sebagai penyebab utama kematian. Sebuah penelitian menunjukkan bahwa resistensi insulin meningkatkan kerentanan pasien mengalami aterosklerosis yang jika tidak dikelola dengan baik dapat berdampak pada peningkatan risiko komplikasi kardiovaskuler (6). Selain itu, resistensi insulin dapat menimbulkan gangguan pada fungsi platelet di pembuluh darah yang juga berperan terhadap peningkatan risiko komplikasi kardiovaskuler (7). Hal ini terbukti pada hasil penelitian yang memaparkan lebih tingginya risiko kejadian komplikasi kardiovaskuler pada pasien DM tipe 2 dengan penyerta dislipidemia dan abnormalitas fungsi platelet $(8,9)$. Komplikasi kardiovaskuler pada akhirnya dilaporkan menjadi penyebab utama dari dua pertiga kematian penderita DM. Beberapa contoh komplikasi kardiovaskuler tersebut secara berturut-turut, yaitu penyakit jantung koroner $(40 \%)$, gagal jantung kongestif (15\%), dan stroke (10\%) (10).

Melihat kerugian yang diakibatkan oleh komplikasi kardiovaskuler, beberapa organisasi kesehatan telah menyarankan upaya-upaya pencegahan melalui pedoman terapi bagi penderita DM tipe 2 . Canadian Cardiovascular Society Guidelines (2011) merekomendasikan penggunaan aspirin dengan dosis 75-162 mg/hari sebagai pencegahan sekunder pada pasien DM tipe 2 yang menjalani terapi rawat jalan dengan komplikasi kardiovaskuler (11). Selain terapi dengan antiplatelet, American Diabetes Association (ADA) juga menambahkan golongan statin sebagai upaya pencegahan sekunder komplikasi kardiovaskuler pada pasien DM tipe 2, demi mencegah keparahan penyakit, mencegah kematian, dan meningkatkan kualitas hidup pasien (12).

Manfaat pemberian statin dan antiplatelet aspirin terhadap penderita DM tipe 2 dibuktikan melalui beberapa jenis penelitian. Statin secara signifikan dapat mencegah mortalitas dan morbiditas pasien DM tipe 2 yang mengalami komplikasi kardio- 
vaskuler secara umum dan penyakit jantung koroner secara lebih spesifik (13-15).

Sementara itu, penelitian mengenai aspirin menyebutkan kemampuannya menurunkan risiko kekambuhan stroke, kejadian infark miokard, dan kematian secara signifikan pada pasien DM tipe 2 (16). Lebih jauh lagi, sebuah studi meta analisis menegaskan keberhasilan aspirin dosis rendah 75 $162 \mathrm{mg} /$ hari) dalam menurunkan komplikasi kardiovaskuler secara signifikan pada penderita DM dengan infark miokard hingga 6,7\% dan stroke iskemik hingga $8,2 \%$ secara berturutturut (17).

Meskipun pemberian statin dan antiplatelet terbukti memberikan keuntungan pada pasien DM tipe 2, data yang tersedia menunjukkan minimnya penggunaan kedua agen tersebut sebagai upaya pencegahan sekunder dalam menurunkan risiko komplikasi kardiovaskuler. Secara berturut-turut penggunaan statin pada pasien DM tipe 2 dengan komplikasi kardiovaskuler di Amerika, Afrika, dan Indonesia dilaporkan sebesar 35,1\%, 36,7\%, dan 25\% (1820). Selanjutnya, peresepan aspirin sebagai pencegahan sekunder komplikasi kardiovaskuler pada pasien DM tipe 2 dilaporkan secara berurutan, yaitu 22,6\%,38,6\%, dan 23,0\% di Thailand, Turki, dan Indonesia (20-22). Dengan demikian, tidak satu pun dari dua pasien DM tipe 2 di beberapa negara tersebut diberikan terapi statin dan antiplatelet untuk mencegah komplikasi kardiovaskuler.

Penelitian terkait yang diselenggarakan di Indonesia baru menampilkan data dari daerah Jawa Timur (20). Melihat rendahnya pemberian statin dan antiplatelet sebagai terapi pencegahan sekunder komplikasi kardiovaskuler serta pertimbangan potensi manfaat terapi tersebut, maka perlu dilakukan penelitian sejenis di daerah berbeda di Indonesia. Penelitian ini bertujuan untuk mengetahui gambaran penggunaan statin dan antiplatelet sebagai pencegahan sekunder pada pasien DM tipe 2 dengan komplikasi kardiovaskuler di Denpasar, Bali.

\section{METODE PENELITIAN}

\section{Rancangan penelitian}

Rancangan penelitian ini adalah observasional dengan desain cross sectional. Kriteria inklusi penelitian meliputi pasien DM tipe 2 rawat jalan dengan komplikasi kardiovaskuler yang telah menyetujui informed consent. Sementara itu, pasien yang mengalami kontraindikasi terhadap obat golongan statin dan antiplatelet serta pasien yang dalam kondisi hamil atau menyusui dieksklusikan dari penelitian ini. Berdasarkan uji pendahuluan populasi yang memenuhi kriteria inklusi dan eksklusi penelitian pada bulan November 2019 sebesar 800 pasien. Dilakukan perhitungan sampel menggunakan rumus Taro Yamane (23) (Gambar 1) dengan menggunakan tingkat presisi 10\%, sehingga diperoleh jumlah sampel minimal sebesar 89 pasien. Peneliti ingin menambahkan jumlah sampel sebesar 10-20\%, sehingga ditetapkanlah 110 subjek untuk penelitian ini. Pengambilan sampel menggunakan teknik purposive sampling.

$$
\begin{aligned}
& \qquad \mathrm{N}=\frac{\mathrm{N}}{\mathrm{Nd}^{2}+1} \\
& \text { Keterangan: } \\
& \mathrm{n}=\text { Jumlah sampel } \\
& \mathrm{N}=\text { Jumlah populasi } \\
& \mathrm{d}^{2}=\text { Presisi yang ditetapkan }(10 \%)
\end{aligned}
$$

\section{Gambar 1. Rumus Taro Yamane.}

\section{Tempat, waktu, dan izin penelitian}

Penelitian dilakukan di RSU Puri Raharja Denpasar, Bali pada 1-30 November 2019. Penelitian ini memperoleh izin penelitian dari RSU Puri Raharja dengan nomor izin penelitian (1699/RSPR/TU/XI/2019).

\section{Pengumpulan dan analisis data}

Pengambilan data dilakukan dengan teknik wawancara langsung kepada pasien untuk memperoleh data terkait nama, usia, jenis kelamin, riwayat penyakit, riwayat keluarga, dan penggunaan obat. Data laboratorium diperoleh dari rekam medik pasien. Kesesuaian penggunaan golongan obat statin dan antiplatelet mengacu pada pedoman terapi Standard of Medical Care in Diabetes oleh ADA tahun 2019 (12). Penilaian kesesuaian dilakukan dengan cara membandingkan karakteristik pasien terhadap kategori kriteria penggunaan obat statin dan antiplatelet sebagai pencegahan sekunder komplikasi kardiovaskuler, sehingga dapat diketahui pasien yang sudah atau belum memperoleh terapi tersebut. Analisis data dilakukan secara deskriptif dengan cara menghitung persentase yang disajikan dalam bentuk tabel.

\section{HASIL DAN PEMBAHASAN}

Subjek penelitian yang memenuhi kriteria inklusi adalah sebanyak 110 pasien. Dari seluruh subjek penelitian yang cenderung terdiri dari pasien berjenis kelamin perempuan $(56,4 \%)$ dan berusia tidak kurang dari 60 tahun (57,3\%), hampir sembilan per sepuluhnya tidak memiliki riwayat kardiovaskuler. Selain itu, hampir tiga perempat pasien DM yang terdata tidak memiliki riwayat keluarga dengan gangguan kardiovaskuler dan tidak merokok. Terlepas dari itu, komplikasi kardiovaskuler yang paling banyak dialami pasien adalah penyakit jantung koroner $(57,3 \%)$. Kondisi penyerta lain yaitu hipertensi, diderita oleh hampir semua pasien, sedangkan dislipidemia hanya diderita oleh sebanyak $40 \%$ dari jumlah total pasien. Meskipun terdapat pasien DM yang disertai dislipidemia, aktivitas pemeriksaan profil lipid darah mencakup Low Density Lipoprotein (LDL), High Density Lipoprotein (HDL), dan trigliserida masih sangat rendah $(<30 \%)$. Data selengkapnya tercantum pada Tabel 1 dan Tabel 2.

Karakteristik pasien dalam penelitian ini mewakili faktorfaktor risiko terjadinya DM, baik yang dapat dimodifikasi maupun tidak dapat dimodifikasi. Seperti yang dijabarkan pada salah satu panduan terapi, merokok termasuk sebagai faktor risiko yang dapat dimodifikasi (12). Sementara itu, jenis kelamin, umur, riwayat penyakit kardiovaskuler keluarga, riwayat penyakit kardiovaskuler yang sudah ada, dan kondisi penyerta lainnya tergolong sebagai faktor risiko yang tidak dapat dimodifikasi $(12,24,25)$. Pengetahuan mengenai faktor-faktor risiko yang dimiliki pasien ini penting dalam manajemen pencegahan sekunder terhadap komplikasi kardiovaskuler. Hal ini disebabkan karena perkembangan komplikasi kardiovaskuler terjadi akibat interaksi antara faktor-faktor risiko tersebut dengan kondisi patofisiologi penyakit DM itu sendiri.

Pasien DM tipe 2 dalam penelitian ini tergolong berisiko lebih tinggi mengalami komplikasi kardiovaskuler, karena mereka lebih banyak berjenis kelamin perempuan $(56,4 \%)$ dan berusia $\geq 60$ tahun $(57,3 \%)$. Hal ini dapat dijelaskan dengan dukungan dari beberapa penelitian sebelumnya. Pertama, perempuan berpeluang memiliki indeks masa tubuh yang lebih besar daripada laki-laki, sehingga berpengaruh pada profil lipid dalam tubuh $(26,27)$. Kedua, perempuan juga disebutkan memiliki nilai advanced glycation end products (AGEs) sebagai penanda risiko penyakit kardiovaskuler yang lebih tinggi daripada laki-laki (28). Ketiga, bertambahnya umur berkaitan dengan penurunan fungsi fisiologis tubuh, penurunan metabolisme lipid, dan peningkatan resistensi insulin $(29,30)$, sehingga kondisi-kondisi ini meningkatkan risiko morbiditas penyakit kardiovaskuler lebih lanjut.

Meskipun dalam persentase yang rendah, riwayat penyakit 
Tabel 1. Karakterisik pasien DM tipe 2

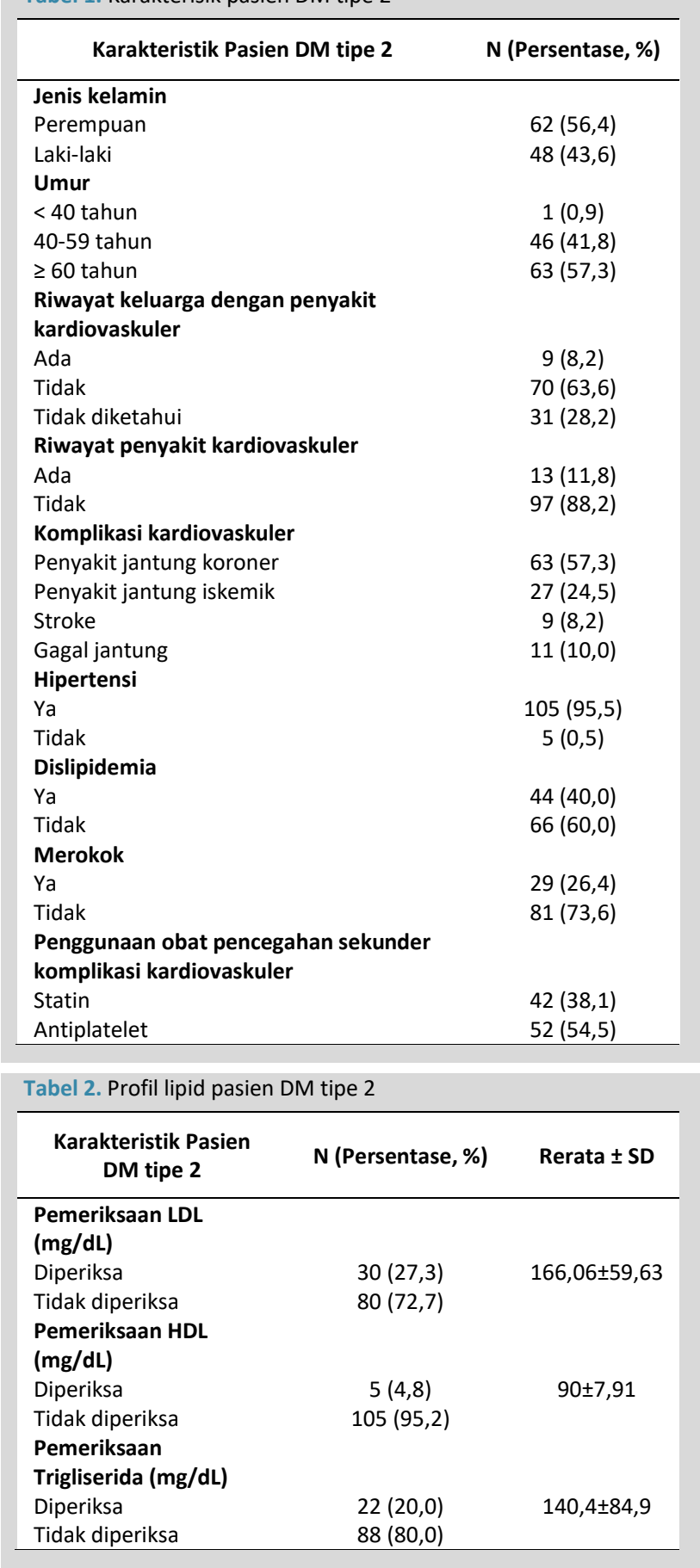

kardiovaskuler yang berasal dari keluarga dan yang terjadi pada pasien DM tipe 2 sebelum penelitian ini juga berperan dalam meningkatkan kerugian terkait komplikasi kardiovaskuler. Pasien yang memiliki riwayat keluarga menderita penyakit kardiovaskuler menunjukkan prevalensi terkena penyakit kardiovaskuler dua kali lipat lebih tinggi $(15,72 \%)$ dibandingkan pasien tanpa riwayat keluarga dengan penyakit kardiovaskuler $(6,25 \%)$ setelah diikuti selama tujuh tahun dalam sebuah studi (31). Sementara itu, kontrol glukosa yang buruk dalam perjalanan penyakit DM tipe 2 meningkatkan risiko komplikasi kronik, baik mikrovaskuler maupun makrovaskuler. Komplikasi yang sering terjadi adalah komplikasi makrovaskuler, khususnya kardiovaskuler $(32,33)$, yang ternyata meningkatkan risiko kematian pasien DM tipe 2 sebanyak 2-4 kali lebih tinggi $(34,35)$. Ditegaskan lagi melalui sebuah studi yang melibatkan 435.369 pasien DM tipe 2 bahwa setelah 4,6 tahun angka kematian akibat komplikasi kardiovaskuler terlaporkan sebesar $17,7 \%$ per tahun. Risiko kematian tersebut lebih tinggi pada pasien DM tipe 2 dengan komplikasi kardiovaskuler $(7,9 \%)$ dibandingkan pasien tanpa komplikasi (6,1\%) (36).

Komplikasi kardiovaskuler yang dialami oleh pasien DM tipe 2 dalam penelitian ini didominasi oleh penyakit jantung koroner (PJK). Hasil ini sejalan dengan dua penelitian sebelumnya yang menunjukkan bahwa komplikasi kardiovaskuler yang paling sering terjadi pada pasien DM tipe 2 adalah PJK dengan etiologi aterosklerosis $(37,38)$. Aterosklerosis merupakan penyempitan dan pengerasan pembuluh darah arteri akibat penumpukan plak kolesterol LDL pada dinding pembuluh darah. Pada patofisiologi DM tipe 2, aterosklerosis dipicu oleh resistensi insulin dan hiperglikemia dalam waktu yang lama (39). Resistensi insulin menyebabkan abnormalitas pada metabolisme lemak dalam tubuh yang terkait dengan kejadian dislipidemia, sedangkan hiperglikemia kronik dapat merusak dinding pembuluh darah yang berujung pada kondisi hipertensi. Perpaduan dislipidemia dan hipertensi inilah yang kemudian memunculkan aterosklerosis (40). Lebih jelas lagi, sebuah penelitian turut melaporkan bahwa sejumlah 38 dari total 200 pasien DM tipe 2 telah mengalami ateroklerosis (37).

Terdapat ketidakselarasan antara kondisi penyerta hipertensi dan dislipidemia, dalam kaitannya terhadap dugaan bahwa pasien DM tipe 2 pada penelitian ini telah mengalami aterosklerosis. Pertama, kondisi hipertensi mendampingi hampir seluruh pasien dalam penelitian ini yang mana data ini konsisten dengan tingginya angka kejadian hipertensi pada pasien DM tipe 2 melalui penelitian di Afrika $(55,0 \%, \mathrm{~N}=140)$ dan Malaysia $(72,1 \%, \mathrm{~N}=154)$ $(41,42)$. Kedua, kondisi dislipidemia yang tidak menyertai separuh dari total pasien DM tipe 2 pada penelitian ini $(44,0 \%)$ bertolak belakang dengan tingginya kejadian dislipidemia $(88,9 \%)$ pada pasien DM tipe 2 yang terlibat $(\mathrm{N}=140.557)$ menurut penelitian terdahulu di salah satu rumah sakit di Thailand (43). Kedua perspektif ini sementara menampilkan bahwa pendukung utama aterosklerosis pada pasien DM tipe 2 di penelitian ini adalah komorbid hipertensi.

Ketidaksesuaian tingkat kejadian dislipidemia dalam penelitian ini sebaiknya tidak dikesampingkan sepenuhnya sebagai kontributor terhadap komplikasi kardiovaskuler. Dislipidemia pada dasarnya merupakan kelainan metabolime lipid yang ditandai oleh peningkatan kadar LDL dan trigliserida serta penurunan kadar HDL dalam darah yang mana ketiganya saling berkaitan dalam proses terjadinya aterosklerosis. Telah dibuktikan bahwa terdapat korelasi yang berbanding lurus antara peningkatan kadar LDL dengan peningkatan risiko penyakit kardiovaskuler (44). Dalam penelitian ini, diantara ketiga data profil lipid yang tercatat, hanya nilai LDL dari pasien DM tipe 2 yang melebihi referensi normal $(166,1 \mathrm{mg} / \mathrm{dL}$ terhadap $<100,0 \mathrm{mg} / \mathrm{dl}$ ) (Tabel 2). Akan tetapi, minimnya jumlah pemeriksaan profil lipid darah pada seluruh pasien yang terlibat dalam penelitian ini kembali menjadi keterbatasan untuk memastikan peranan dislipidemia terhadap komplikasi kardiovaskuler yang terjadi.

Selain memperhatikan komorbid, faktor risiko gaya hidup merokok yang terdata dalam penelitian ini juga berkaitan dengan kejadian DM tipe 2 dan komplikasi kardiovaskuler. Kandungan nikotin pada rokok memperburuk sensitivitas insulin melalui perangsangan molekul pemberi sinyal mammalian target of rapamycin (mTOR) agar memicu abnormalitas pertumbuhan sel yang mengganggu tanggapan reseptor insulin. Nikotin juga menekan sekresi insulin melalui aktivasi hormon katekolamin $(45,46)$. Dalam kaitannya dengan komplikasi kardiovaskuler, paparan nikotin secara berkepanjangan dapat menurunkan jumlah antioksidan tubuh, memicu stres oksidatif, dan meningkatkan jumlah radikal bebas. Secara singkat, ketiga hal tersebut akhirnya memicu disfungsi endotel, penyempitan pembuluh 


\begin{tabular}{|c|c|c|c|c|}
\hline No & Kriteria penilaian kesesuaian penggunaan statin & $\begin{array}{c}\text { Jumlah pasien yang } \\
\text { memenuhi kriteria } \\
\text { penggunaan statin } \\
(\%)\end{array}$ & $\begin{array}{l}\text { Jumlah pasien yang } \\
\text { menggunakan statin } \\
\text { (\%) }\end{array}$ & $\begin{array}{c}\text { Jumlah pasien yang } \\
\text { tidak menggunakan } \\
\text { statin (\%) }\end{array}$ \\
\hline 1. & Terdapat riwayat penyakit kardiovaskuler yang diketahui & $13(11,8)$ & $5(4,5)$ & $8(7,3)$ \\
\hline \multirow[t]{2}{*}{2.} & $\begin{array}{l}\text { Riwayat penyakit kardiovaskuler yang tidak diketahui, } \\
\text { namun memiliki kriteria yaitu: } \\
\text { a. Usia } 40-75 \text { tahun } \\
\text { b. Memiliki minimal satu faktor risiko kardiovaskuler yaitu } \\
\text { riwayat keluarga menderita penyakit kardiovaskuler, } \\
\text { LDL } \geq 100 \mathrm{mg} / \mathrm{dL} \text {, diagnosis hipertensi, merokok, } \\
\text { obesitas, diagnosis dyslipidemia, albuminuria serta } \\
\text { diagnosis gagal ginjal kronik }\end{array}$ & $97(88,2)$ & $37(33,6)$ & $60(54,6)$ \\
\hline & Total & $110(100)$ & $42(38,1)$ & $68(61,9)$ \\
\hline
\end{tabular}

darah, peningkatan resistensi tahanan perifer, dan pembentukan aterosklerosis. Nikotin juga merangsang hormon adrenalin yang meningkatkan kerja jantung (47). Sama halnya dengan kejadian dislipidemia, pasien yang merokok dalam penelitian ini tidak tergolong banyak $(26,4 \%)$ Walaupun demikian, mempertimbangkan dominasi komplikasi PJK pada pasien DM tipe 2 di penelitian ini, maka salah satu atau semua faktor risiko yang telah didiskusikan di atas tentu telah berkontribusi dalam menyebabkan aterosklerosis hingga penyempitan arteri koronaria pada jantung.

Selanjutnya, hasil pada penelitian ini menampilkan profil kesesuaian penggunaan statin dan antiplatelet dalam upaya pencegahan sekunder komplikasi kardiovaskuler berdasarkan ketentuan ADA (2019) (12) yang hampir mirip antara keduanya. Terkait penggunaan statin, seluruh subjek penelitian memenuhi kriteria yang disampaikan pada pedoman terapi oleh ADA (2019) (Tabel 3). Dari 11,8\% pasien yang diketahui memiliki riwayat penyakit kardiovaskuler, hanya 4,5\% yang memperoleh statin. Sama halnya pada $88,2 \%$ pasien lainnya yang tidak memiliki riwayat penyakit kardiovaskuler namun memenuhi kriteria yang dipersyaratkan untuk terapi statin, hanya sepertiga yang mendapatkan statin. Jenis statin yang paling banyak diresepkan adalah simvastatin dengan dosis $20 \mathrm{mg}$ per hari $(95,2 \%)$ (Tabel 4). Lebih sedikit dari jumlah pasien yang memenuhi kriteria penggunaan statin, sebanyak 96 pasien $(87,3 \%)$ masuk dalam kriteria penggunaan antiplatelet menurut ADA (2019) (12) (Tabel 5). Dari jumlah tersebut, pasien penerima resep antiplatelet pada kelompok yang diketahui memiliki riwayat penyakit kardiovaskuler masih rendah $(4,5 \%)$ menyerupai persentase data pada kriteria terkait penggunaan statin. Akan tetapi, pasien tanpa penyakit kardiovaskuler yang memenuhi syarat berjumlah sedikit lebih banyak diberikan antiplatelet $(42,8 \%)$ dibandingkan pasien dengan kategori yang sama menurut kriteria pemberian statin. Jenis antiplatelet yang paling banyak diresepkan adalah aspirin dengan dosis $80 \mathrm{mg}$ per hari $(82,7 \%)$ (Tabel 6).

Beberapa studi pendahulu mengenai penggunaan statin sebagai pencegahan sekunder komplikasi kardiovaskuler pada pasien DM tipe 2 menampilkan profil yang bervariasi. Satu penelitian kohort retrospektif di Amerika yang mengikuti perkembangan sebanyak 899.664 pasien DM selama 9 tahun (2003-2011) melaporkan bahwa dari sekitar separuh jumlah total pasien tersebut, hanya 40,5\% (200.180) yang menerima statin (48). Penelitian lainnya yang juga dilakukan di suatu rumah sakit di Amerika melibatkan 8.499 pasien DM dengan komplikasi PJK. Diantara mereka terdapat 12,5\% ( $\mathrm{N}=1.061$ ) yang belum memperoleh terapi statin (15). Dibandingkan terhadap dua contoh penelitian tersebut, tingkat penggunaan statin dari hasil penelitian ini $(<40 \%$, Tabel 3$)$ cenderung sedikit lebih rendah daripada penelitian pertama dan bahkan jauh lebih rendah daripada penelitian kedua.

\begin{tabular}{llcc}
\multicolumn{4}{l}{ Tabel } \\
\hline No & Golongan dan dosis penggunaan statin \\
\hline 1. & Atorvastatin & $\begin{array}{c}\text { Dosis } \\
\text { (per hari) }\end{array}$ & $\begin{array}{c}\text { Persentase jumlah } \\
\text { pasien (\%) }\end{array}$ \\
2. & Simvastatin & $20 \mathrm{mg}$ & $1(2,4)$ \\
3. & Rosuvastatin & $20 \mathrm{mg}$ & $40(95,2)$ \\
& Total & & $1(2,4)$ \\
\hline
\end{tabular}

Disisi lain, dua penelitian sebelumnya terkait penggunaan antiplatelet pada pasien DM tipe 2 juga memberikan konsistensi variasi hasil. Penelitian pertama menunjukkan hanya 38\% dari total 910 pasien DM tipe 2 disertai dislipidemia dan komplikasi kardiovaskuler yang menerima aspirin (22). Penelitian kedua melaporkan penggunaan lebih tinggi, karena dengan persentase yang hampir sama $(36,7 \%)$ justru menunjukkan jumlah pasien DM tipe 2 yang belum menerima aspirin dari total 1.256 subjek (49). Terhadap dua penelitian tersebut, tingkat penggunaan antiplatelet menurut hasil dari penelitian ini mengambil posisi di tengah-tengah, tetapi belum mencapai separuh dari total pasien DM tipe 2 yang terlibat (47,3\%, Tabel 5).

Rendahnya penggunaan statin dan antiplatelet sebagai upaya pencegahan sekunder komplikasi kardiovaskuler pada DM tipe 2 pada penelitian ini menandakan belum sempurnanya pelaksanaan anjuran dari beberapa pedoman terapi yang relevan. ADA (2019) menyatakan bahwa dibutuhkan terapi golongan statin dan antiplatelet sebagai pencegahan sekunder pada pasien DM tipe 2 yang mengalami komplikasi kardiovaskuler (12). Statin merupakan pengobatan lini pertama yang direkomendasikan untuk mengontrol dan menurunkan profil lipid pasien DM tipe 2. Selain itu, antiplatelet aspirin juga dibutuhkan dengan dosis 75-162 mg per hari untuk pencegahan sekunder pada pasien DM tipe 2 dengan riwayat menderita aterosklerosis maupun komplikasi kardiovaskuler. American Heart Association (AHA) dan American College of Cardiology Foundation (ACCF) juga menyarankan terkait kewajiban menggunakan antiplatelet sebagai pencegahan sekunder pada pasien yang mengalami penyakit kardiovaskuler seperti PJK (50). Melihat tingginya jumlah pasien DM tipe 2 , anjuran-anjuran terkait pencegahan sekunder tersebut sebetulnya menguntungkan dan berpotensi dalam menurunkan keparahan penyakit serta risiko kematian.

Keuntungan pemberian statin sebagai pencegahan sekunder komplikasi kardiovaskuler diyakinkan oleh beberapa studi dan dijelaskan dengan beberapa mekanisme. Studi-studi kebanyakan melaporkan bahwa penggunaan statin efektif dalam mencegah keparahan PJK, infark miokard, stroke, dan bahkan kematian (51-53). Hal ini dikarenakan statin memiliki efek yang dapat menurunkan biosintesis kolesterol dan menurunkan profil lipid. Statin mampu mengurangi kadar LDL (20-55\%) dan trigliserida (7-30\%) serta mening- 


\begin{tabular}{|c|c|c|c|c|}
\hline No & Kriteria penilaian kesesuaian & $\begin{array}{c}\text { Jumlah pasien yang } \\
\text { memenuhi kriteria } \\
\text { penggunaan } \\
\text { antiplatelet (\%) }\end{array}$ & $\begin{array}{c}\text { Jumlah pasien yang } \\
\text { menggunakan } \\
\text { antiplatelet (\%) }\end{array}$ & $\begin{array}{c}\text { Jumlah pasien yang } \\
\text { tidak menggunakan } \\
\text { antiplatelet (\%) }\end{array}$ \\
\hline 1. & Terdapat riwayat penyakit kardiovaskuler yang diketahui & $13(11,8)$ & $5(4,5)$ & $8(7,3)$ \\
\hline \multirow[t]{2}{*}{2.} & $\begin{array}{l}\text { Riwayat penyakit kardiovaskuler yang tidak diketahui, } \\
\text { namun memiliki kriteria yaitu: } \\
\text { a. Berusia > } 50 \text { tahun } \\
\text { b. Memiliki minimal satu faktor risiko kardiovaskuler } \\
\text { yaitu riwayat keluarga menderita penyakit } \\
\text { kardiovaskuler, diagnosis hipertensi, dislipidemia, } \\
\text { albuminuria atau gagal ginjal kronik, merokok }\end{array}$ & $83(75,5)$ & $47(42,8)$ & $36(32,7)$ \\
\hline & Total & $96(87,3 \%)$ & $52(47,3)$ & $44(40)$ \\
\hline
\end{tabular}

katkan HDL (5-10\%) dengan mekanisme kerja melalui penghambatan enzim $\beta$-hidroksi $\beta$-metilglutaril-CoA (HMG$\mathrm{CoA}$ ) reduktase yang berperan pada sintesis kolesterol di hati (54). Selain itu, statin juga memberikan efek pleiotropik pada tubuh sebagai antiinflamasi, peningkat fungsi endotel pembuluh darah, dan imunomodulator (55).

\begin{tabular}{llcc}
\multicolumn{4}{l}{ Tabel 6. Golongan dan dosis penggunaan antiplatelet } \\
\hline No & Golongan & $\begin{array}{c}\text { Dosis } \\
\text { (per hari) }\end{array}$ & $\begin{array}{c}\text { Persentase jumlah } \\
\text { pasien (\%) }\end{array}$ \\
\hline 1. & Aspirin & $80 \mathrm{mg}$ & $43(82,7)$ \\
2. & Klopidogrel & $75 \mathrm{mg}$ & $9(17,3)$ \\
& Total & & $\mathbf{5 2 ( 1 0 0 )}$ \\
\hline
\end{tabular}

Rendahnya penggunaan statin pada penelitian ini dapat disebabkan oleh dua hal berikut. Pertama, terdapat perbedaan pandangan klinisi terkait kondisi pasien yang memerlukan pengobatan statin. Kedua, tidak dilakukannya pemeriksaan terhadap profil lipid, sehingga mempengaruhi peresepan kepada pasien yang ditetapkan berdasarkan kriteria formularium nasional yang dikeluarkan oleh Badan Penyelenggara Jaminan Sosial (BPJS). Berdasarkan formularium nasional (2018) golongan statin sebagai terapi tambahan pada pasien hiperlipidemia diberikan apabila kadar LDL >130 mg/dL disertai penyakit DM, kadar LDL >160 $\mathrm{mg} / \mathrm{dL}$ tanpa penyakit DM dan PJK atau pasien dengan diagnosis atherosclerotic cardiovasculer disease (ASCVD), seperti post-percutaneous coronary intervention (PCI), coronary artery bypass Graft (CABG), stroke iskemik dan/ atau peripheral artery disease (PAD), serta pasca-infark yang dibuktikan dengan elektrokardiografi, pindaian tomografi MSCT, atau riwayat angiografi (56).

Diantara rendahnya pemakaian statin pada penelitian ini, jenis statin yang paling banyak diresepkan adalah simvastatin dengan dosis $20 \mathrm{mg}$ per hari yang mana sesuai dengan pedoman terapi pasien DM tipe 2 dan rasional efektivitasnya. Penggunaan simvastatin yang paling banyak seperti penelitian ini juga terjadi pada penelitian terhadap pasien DM tipe 2 di Malaysia, yaitu dengan rentang dosis 10 $40 \mathrm{mg}(51,2 \%)$ (57). Pada pedoman terapi, ADA (2019) memang merekomendasikan pemberian golongan statin dengan dosis 20-40 mg/hari untuk pasien DM tipe 2 dengan penyakit kardiovaskuler disertai kadar LDL $\geq 70 \mathrm{mg} / \mathrm{dL}$. Penyesuaian dosis mengikuti kondisi klinik pasien yang mencakup respon terhadap obat serta efek samping setelah pemberian obat (12). Sebuah pedoman terapi lain mengkaji perbedaan efektivitas golongan statin dalam menurunkan profil lipid, bahwa penggunaan atorvastatin dengan dosis 20 mg dapat menurunkan kadar LDL sebesar 39-45\% dengan risiko efek samping yang minimal dan waktu paruh yang panjang (13-33 jam). Hal inilah yang mendukung penggunaan atorvastatin sebanyak satu kali dalam sehari dengan jaminan keamanan untuk digunakan pada pasien dengan gangguan fungsi ginjal (58). Selain itu, tingginya penggunaan simvastatin pada penelitian ini disebabkan karena seluruh pasien menggunakan jaminan kesehatan dari BPJS, sehingga peresepan yang diberikan mengikuti ketentuan formularium nasional. Simvastatin diberikan apabila selama 3 bulan berturut-turut pasien tidak mencapai target penurunan LDL $<100 \mathrm{mg} / \mathrm{dL}$ dengan hanya pola diet yang diatur (56).

Selain statin, dukungan penelitian terdahulu dan mekanisme aksi dari pengobatan dengan antiplatelet aspirin dijelaskan sebagai berikut. Sebuah studi membuktikan bahwa penggunaan aspirin untuk pencegahan sekunder terhadap penyakit kardiovaskuler menurunkan risiko kejadian infark miokard, stroke berulang, dan kematian melebihi 20\% $(59,60)$. Pooled data pada dua meta analisis dari sejumlah studi klinis yang mencakup sekitar belasan ribu individu masing-masing dengan risiko tinggi mengalami kejadian kardiovaskuler dan dengan DM, mengaitkan aspirin dengan risiko kejadian kardiovaskuler parah, seperti kematian, yang lebih rendah dibandingkan dengan kontrol $(6,7 \%$ terhadap $8,2 \%, \quad p<0,0001 ; \quad R R=0,82,95 \%, p=0,03) \quad(61,62)$. Efek pencegahan ini berasal dari mekanisme aspirin dalam menghambat enzim siklooksigenase sebagai pengatur sintesis tromboksan A2 (TXA2) yang menyebabkan agregasi trombosit. Aspirin juga memiliki efek antiinflamasi yang dapat mengurangi ruptur plak dalam patofisiologi aterosklerosis (63).

Terlepas dari masih kurangnya penggunaan antiplatelet sebagai pencegahan sekunder komplikasi kardiovaskuler pasien DM tipe 2 dalam penelitian ini, dua jenis obat yang dilaporkan telah sesuai dengan pedoman terapi. Dosis aspirin $80 \mathrm{mg}$ per hari dalam penelitian ini sesuai dengan pedoman keluaran ADA (2019) yang mana aspirin merupakan obat lini pertama (12). Selain aspirin, sebagian kecil pasien pengguna antiplatelet dalam studi ini menggunakan klopidogrel $(17,3 \%)$. Apabila pasien mengalami kontraindikasi terhadap aspirin, klopidogrel sebagai lini kedua dapat digunakan (64). Klopidogrel sendiri cenderung memiliki efek samping pada lambung yang relatif lebih aman dibandingkan aspirin. Hal ini dikarenakan klopidogrel bukan bekerja menghambat enzim siklooksigenase yang menghambat pembentukan prostaglandin untuk melindungi mukosa lambung, melainkan menghambat adenosine diphosphate (ADP) dengan mengikat reseptor $\mathrm{P} 2 \mathrm{Y} 12$ pada permukaan trombosit, sehingga mencegah aktivasi dan agregasi trombosit yang diinduksi oleh ADP $(65,66)$.

\section{KESIMPULAN}

Penelitian ini merefleksikan penggunaan statin yang masih rendah dalam upaya pencegahan sekunder komplikasi kardiovaskuler pada pasien DM tipe 2 di Denpasar. Meskipun terdapat kecenderungan tingkat penggunaan antiplatelet aspirin yang lebih tinggi daripada statin dalam penelitian ini, pemberian aspirin selanjutnya masih perlu ditingkatkan lagi bersama-sama dengan peningkatan pemberian statin. Optimalisasi pencegahan sekunder komplikasi kardiovaskuler pada DM tipe 2 perlu ditingkatkan oleh para praktisi 
klinis, mempertimbangkan besarnya manfaaat yang diperoleh untuk meminimalkan morbiditas dan mortalitas penderitanya. Namun demikian, pengaplikasian hasil penelitian ini pada situasi klinis tertentu di tempat lain perlu memperhatikan keterbatasan penelitian, seperti jumlah sampel dan perbedaan karakteristik subjek penelitian.

\section{UCAPAN TERIMA KASIH}

Penulis mengucapkan terima kasih kepada pihak rumah sakit serta berbagai pihak yang telah membantu selama proses penelitian.

\section{DAFTAR PUSTAKA}

1. Roglic G, Varghese C, Riley L, Harvey A, Krug E, Alwan A. Global report on diabetes. Roglic G, editor. Geneva, Switzerland: World Health Organization; 2016.

2. Williams R, Colagiuri S, Almutairi R, Montoya P, Basit A, Beran D. IDF Diabetes Atlas Ninth edition 2019. International Diabetes Federation. 2019.

3. Cho N, Kirigia J, Mbanya J, Ogurstova K, Guariguata L, Rathmann W. IDF Diabetes Atlas Eighth Edition 2017. IDF Diabetes Atlas, 8th edition. 2017.

4. Kazi AA, Blonde L. Classification of diabetes mellitus. Clin Lab Med. 2019;21(1):1-13.

5. Sulistyowati L. Kebijakan Pengendalian DM di Indonesia. Simp WDD 2017;121-30.

6. Yang W, Cai X, Han X, Ji L. Clinical Characteristics of Young Type 2 Diabetes Patients with Atherosclerosis. Feng Y-M, editor. PLoS One [Internet]. 2016 Jul 8;11(7):1-8. Available from doi:10.1371/journal.pone.0159055

7. Capodanno D, Angiolillo DJ. Aspirin for Primary Cardiovascular Risk Prevention and beyond in Diabetes Mellitus. Circulation. 2016;134(20):1579-94.

8. Gonna H, Ray KK. The importance of dyslipidaemia in the pathogenesis of cardiovascular disease in people with diabetes. Diabetes, Obes Metab. 2019;21(S1):6-16.

9. Goel S, Garg P, Malhotra V, Madan J, Mitra S, Grover S. Dyslipidemia in Type II Diabetes Mellitus - An assessment of the main lipoprotein abnormalities. Bangladesh J Med Sci. 2016;15(1):99-102.

10. Low Wang CC, Hess CN, Hiatt WR, Goldfine AB. Clinical update: Cardiovascular Disease in Diabetes Mellitus. Circulation. 2016;133(24):2459-502.

11. Bell A, Roussin A, Cartier R, Teal P, Théroux P, Turpie A, et al. The Use of Antiplatelet Therapy in the Outpatient Setting: Canadian Cardiovascular Society Guidelines Executive Summary. Can J Cardiol [Internet] 2011;27(2):208-21. Available http://dx.doi.org/10.1016/j.cjca.2010.12.033

12. Riddle M, Bakris G, Blonde L, Boulton A. American Diabetes Association Standards of Medical Care In Diabetes-2019. J Clin Apllied Res Educ Diabetes Care [Internet]. 2019;42(1):54-67. Available from: http://repositorio.unan.edu.ni/2986/1/5624.pdf

13. Naeem F, McKay G, Fisher M. Cardiovascular outcomes trials with statins in diabetes. Br J Diabetes. 2018;18(1):101-5.

14. Jaiswal M, Schinske A, Pop-Busui R. Lipids and lipid management in diabetes. Best Pract Res Clin Endocrinol Metab [Internet] 2014.28(3):325-38.

Available http://dx.doi.org/10.1016/j.beem.2013.12.001

15. Zhang H, Plutzky J, Shubina M, Turchin A. Risk factors for lack of statin therapy in patients with diabetes and coronary artery disease. J Clin Lipidol. 2016;10(6):1406-13.

16. Ansa B, Hoffman Z, Lewis N, Savoy C, Hickson A, Stone R, et al. Aspirin Use among Adults with Cardiovascular Disease in the United States: Implications for an Intervention Approach. J Clin Med. 2019;8(2):264.

17. Kim J, Shim M, Lee S, Oh J. Aspirin for primary prevention of cardiovascular disease. J Lipid Atheroscler. 2019;8(2):162-72.

18. Pauff B, Jiroutek M, Holland M, Sutton B. Statin Prescribing Patterns: An Analysis of Data from Patients with Diabetes in the National Hospital Ambulatory Medical Care Survey Outpatient Department and National Ambulatory Medical Care Survey Databases, 2005-2010. Clin Ther [Internet]. 2015;37(6):1329-39. Available from: http://dx.doi.org/10.1016/j.clinthera.2015.03.020

19. Melaku T, Solomon Y, Chelkeba L. Statin Utilization Patterns among Type 2 Diabetes Mellitus Patients with High Cardiovascular Disease Risks in Ethiopia. J Pharm Care. 2018;6(3):44-51.

20. Lie PGCE, Irawati S, Presley B. Prevention of Cardiovascular Disease in Diabetes Mellitus Outpatient: Focusing on Antiplatelet, Statins and Irrational Antihypertensive Drug Use. Indones J Clin Pharm. 2016;5(3):169-83.

21. Chootong R, Jamulitrat S. Prevalence of Aspirin Prescriptions among Type 2 Diabetic Patients in Songklanagarind Hospital. Songklanagarind Med J. 2018;36(1):35-44.

22. Karaca A, Yakar B. Frequency of aspirin use in patients with type 2 diabetes: Is there any effect of concomitant diseases? Ann Med Res. 2019;26(12):2952-6.

23. Jaya I. Penerapan Statistik Untuk Penelitian Pendidikan. 1th ed. Jakarta, Indonesia: Prenadamedia Group (Divisi Kencana); 2019.
24. Maahs DM, Daniels SR, De Ferranti SD, Dichek HL, Flynn J, Goldstein BI, et al. Cardiovascular Disease Risk Factors in Youth with Diabetes Mellitus: A Scientific Statement from the American Heart Association. Circulation. 2014;130(17):1532-58.

25. McNeill JA, Cook JDM, Mahon M, Allwein DA, Rauschhuber M, Richardson CO, et al. A Family History Intervention Enhancing Cardiovascular Risk Assessment. AAOHN J. 2011;59(4):181-94.

26. Anagnostis P, Majeed A, Johnston DG, Godsland IF. Mechanisms in endocrinology: Cardiovascular risk in women with type 2 diabetes mellitus and prediabetes: Is it indeed higher than men? Eur J Endocrinol. 2014;171(6):R245-55.

27. Huebschmann AG, Huxley RR, Kohrt WM, Zeitler P, Regensteiner JG, Reusch JEB. Sex differences in the burden of type 2 diabetes and cardiovascular risk across the life course. Diabetologia [Internet]. 2019;62(10):1761-72. Available http://dx.doi.org/10.1007/s00125-019-4939-5

28. Kanamori M, Selim M, Takiddin A, Al-Homsi H, Al-Mahmoud K. Ethnic and gender differences in advanced glycation end products measured by skin auto-fluorescence. Dermatoendocrinol. 2013;5(2):325-30.

29. Chia CW, Egan JM, Ferrucci L. Age-related changes in glucose metabolism, hyperglycemia, and cardiovascular risk. Circ Res. 2018;123(7):886-904.

30. Lascar N, Brown J, Pattison H, Barnett AH, Bailey CJ, Bellary S. Type 2 diabetes in adolescents and young adults. Lancet Diabetes Endocrinol. 2018;6(1):69-80.

31. Moonesinghe R, Yang Q Zhang Z, Khoury MJ. Prevalence and Cardiovascular Health Impact of Family History of Premature Heart Disease in the United States: Analysis of the National Health and Nutrition Examination Survey, 2007-2014. J Am Heart Assoc. 2019;8(14):1-11.

32. Domeikiene A, Vaivadaite I, Ivanauskiene R, Padaiga Z. ScienceDirect Direct cost of patients with type 2 diabetes mellitus healthcare and its complications in Lithuania. Mediciana. 2014;S4-6.

33. Chappidi M, Shivananjiah S, Thirthahalli C, Kunnavil R, Chappidi M, Med JC, et al. Complications of diabetes mellitus among patients attending the out- patient department of a tertiary care hospital. Int J Community Med Public Heal. 2018;5(1):341-8.

34. Fan W. Epidemiology in diabetes mellitus and cardiovascular disease. Cardiovasc Endocrinol. 2017;6(1):8-16.

35. Bertoluci MC, Rocha VZ. Cardiovascular risk assessment in patients with diabetes. Diabetol Metab Syndr. 2017;9(25):1-13.

36. Tancredi M, Rosengren A, Svensson AM, Kosiborod M, Pivodic A Gudbjörnsdottir S, et al. Excess mortality among persons with type 2 diabetes. N Engl J Med. 2015;373(18):1720-32.

37. Khanam PA, Begum T, Chowdhury A, Habib SH. Coronary artery disease with type 2 diabetes and other risk factors: A tertiary care hospital in Bangladesh. Bangladesh Crit Care J. 2019;7(1):20-5.

38. Jelinek HF, Osman WM, Khandoker AH, Khalaf K, Lee S, Almahmeed W, et al. Clinical profiles, comorbidities and complications of type 2 diabetes mellitus in patients from United Arab Emirates. BMJ Open Diabetes Res Care. 2017;5(1):1-9.

39. Haas A V., McDonnell ME. Pathogenesis of Cardiovascular Disease in Diabetes. Endocrinol Metab Clin North Am [Internet]. 2018;47(1):51-63. Available from: https://doi.org/10.1016/j.ecl.2017.10.010

40. Abdul-Ghani M, DeFronzo RA, Del Prato S, Chilton R, Singh R, Ryder REJ. Cardiovascular disease and type 2 diabetes: Has the dawn of a new era arrived? Diabetes Care. 2017;40(7):813-20.

41. Tadesse K, Amare H, Hailemariam T, Gebremariam T. Prevalence of Hypertension among Patients with Type 2 Diabetes Mellitus and Its Socio Demographic Factors in Nigist Ellen Mohamed Memorial Hospital Hosanna, Southern Ethiopia. J Diabetes Metab. 2018;9(4):4-10.

42. Abdullah F, Han TM, Nor MBM, Mohd Aznan MA, Ismail IZ. Prevalence of hypertension and glycaemic control in adult type-2 diabetes patients: A preliminary retrospective cohort study in Kuantan, Pahang, Malaysia. Int Med J Malaysia. 2017;16(1):115-22.

43. Narindrarangkura P, Bosl W, Rangsin R, Hatthachote P. Prevalence of dyslipidemia associated with complications in diabetic patients: A nationwide study in Thailand. Lipids Health Dis. 2019;18(1):1-8.

44. 4Sarwar N, Gao P, Kondapally Seshasai SR, Gobin R, Kaptoge S, Di Angelantonio E, et al. Diabetes mellitus, fasting blood glucose concentration, and risk of vascular disease: A collaborative meta-analysis of 102 prospective studies. Lancet [Internet]. 2010;375(9733):2215-22. Available from: http://dx.doi.org/10.1016/S0140-6736(10)60484-9

45. Sliwinska-Mosson M, Milnerowicz $H$. The impact of smoking on the development of diabetes and its complications. Diabetes Vasc Dis Res. 2017;14(4):265-76

46. Bajaj M. Nicotine and insulin resistance: When the smoke clears. Diabetes. 2012;61(12):3078-80.

47. George P, Mamali A, Papafloratos S, Zerva E. Effects of Smoking on Cardiovascular Function: The Role of Nicotine and Carbon Monoxide Institution of Athens (TEI-A), Greece 2. Physical Therapy Department, Technological Educational Institution of Athens (TEI-A), Greece 3. Physical Therapy Department, T. Heal Sci J [Internet]. 2014;8(2):274-90. Available from: http://www.hsj.gr/medicine/effects-of-smoking-oncardiovascular-function-the-role-of-nicotine-and-carbon-monoxide.pdf

48. Brennan MB, Huang ES, Lobo JM, Kang H, Guihan M, Basu A, et al. Longitudinal trends and predictors of statin use among patients with diabetes. J Diabetes Complications. 2018;32(1):27-33.

49. Ghadiri-Anari A, Jafari-Mehdiabad AH, Afkhami-Ardekani M, Rezapour M, Chavoshzadeh-Tafti F. Prevalence of Aspirin Use among Type 2 Diabetic Patients in Iran. Iran J Diabetes Obes. 2013;5(4):171-5.

50. Smith SC, Benjamin EJ, Bonow RO, Braun LT, Creager MA, Franklin BA, et al. AHA/ACCF secondary prevention and risk reduction therapy for 
patients with coronary and other atherosclerotic vascular disease: 2011 update: A guideline from the American Heart Association and American College of Cardiology Foundation. Circulation. 2011;124(22):2458-73

51. Jellinger PS, Handelsman Y, Rosenblit PD, Bloomgarden ZT, Fonseca VA Garber AJ, et al. American Association of Clinical Endocrinologists and American College of Endocrinology Guidelines for Management of Dyslipidemia and Prevention of Cardiovascular Disease. Endocr Pract. 2017;23(2):1-87.

52. Rodriguez F, Maron DJ, Knowles JW, Virani SS, Lin S, Heidenreich PA Association between intensity of statin therapy and mortality in patients with atherosclerotic cardiovascular disease. JAMA Cardiol. 2017;2(1):47-54.

53. Navarese EP, Robinson JG, Kowalewski M, Kołodziejczak M, Andreotti F, Bliden $\mathrm{K}$, et al. Association between baseline LDL-C level and total and cardiovascular mortality after LDL-C lowering a systematic review and meta-analysis. JAMA - J Am Med Assoc. 2018;319(15):1566-79.

54. Martinez-Hervas S, Carmena R, Ascaso JF. Significance of LDL-C lowering therapy in diabetic patients. Clin Lipidol. 2011;6(4):389-99.

55. Rohilla A, Rohilla S, Kumar A, Khan MU, Deep A. Pleiotropic effects of statins: A boulevard to cardioprotection. Arab J Chem [Internet]. 2016;9:S21-7. Available

http://dx.doi.org/10.1016/j.arabjc.2011.06.025

56. Kementerian Kesehatan Republik Indonesia. Formularium Nasional HK.01.07/MENKES/707/2017. 2018;121.

57. Elnaem MH, Nik Mohamed MH, Huri HZ, Azarisman SM. Patterns of statin therapy prescribing among hospitalized patients with type 2 diabetes mellitus in two Malaysian tertiary hospitals. Trop J Pharm Res. 2017;16(12):3005-11.

58. Rhee E, Kim HC, Kim JH, Lee EY, Kim BJ, Kim EM, et al. 2018 Guidelines for the management of dyslipidemia Cardiovascular disease in Koreans. Korean J Intern Med [Internet]. 2019;34(4):723-71. Available from http://kjim.org/journal/view.php?doi=10.3904/kjim.2019.188
59. Nicolucci A, Standl E. Antiplatelet therapy for every diabetic person? Diabetes Care. 2011;34(SUPPL. 2):S150-4

60. Godley RW, Hernandez-Vila E. Aspirin for primary and secondary prevention of cardiovascular disease. Texas Hear Inst J. 2016;43(4):3189.

61. Collins R, Peto R, Hennekens C, Doll R, Bubes V, Buring J, et al. Aspirin in the primary and secondary prevention of vascular disease: collaborative meta-analysis of individual participant data from randomised trials. Lancet [Internet]. 2009;373(9678):1849-60. Available from: http://dx.doi.org/10.1016/S0140-6736(09)60503-1

62. Simpson SH, Gamble JM, Mereu L, Chambers T. Effect of aspirin dose on mortality and cardiovascular events in people with diabetes: A metaanalysis. J Gen Intern Med. 2011;26(11):1336-44.

63. Bell DSH. Aspirin in the prevention of cardiovascular events in patients with diabetes. Postgrad Med [Internet]. 2016;128(2):180-90. Available from: http://dx.doi.org/10.1080/00325481.2016.1131106

64. Powers WJ, Rabinstein AA, Ackerson T, Adeoye OM, Bambakidis NC, Becker $\mathrm{K}$, et al. Guidelines for the early management of patients with acute ischemic stroke: 2019 update to the 2018 guidelines for the early management of acute ischemic stroke a guideline for healthcare professionals from the American Heart Association/American Stroke A. Vol. 50, Stroke. 2019. 344-418 p.

65. Hackam DG, Spence JD. Antiplatelet therapy in ischemic stroke and transient ischemic attack: An overview of major trials and meta-analyses. Stroke. 2019;50(3):773-8.

66. Eikelboom JW, Hirsh J, Spencer FA, Baglin TP, Weitz JI. Antiplatelet drugs - Antithrombotic therapy and prevention of thrombosis, 9th ed: American College of Chest Physicians evidence-based clinical practice guidelines. Chest [Internet]. 2012;141(2 SUPPL.):e89S-e119S. Available from: http://dx.doi.org/10.1378/chest.11-2293 